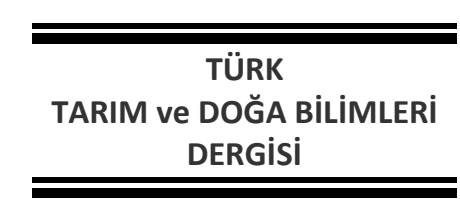

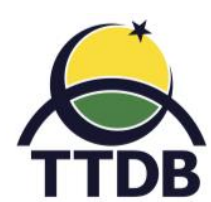

www.dergipark.gov.tr/turkjans

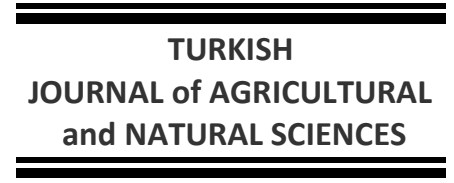

Araştırma Makalesi

\title{
Türkiye'de Ticari Fasulye (Phaseolus vulgaris L.) Çeşitlerinde Bean common mosaic virus ve Bean common mosaic necrosis virus Etmenlerine Dayanıklılıkla ỉiş̧kili Genlerin Karakterizasyonu
}

\author{
Mehmet Zahit YEKEN ${ }^{1}$, Göksel ÖZER ${ }^{2}$, Ali ÇELiK ${ }^{2 *}$, Vahdettin ÇiFTÇi ${ }^{1}$
}

${ }^{1}$ Bolu Abant İzzet Baysal Üniversitesi, Ziraat ve Doğa Bilimleri Fakültesi, Tarla Bitkileri Bölümü, BOLU

${ }^{2}$ Bolu Abant İzzet Baysal Üniversitesi, Ziraat ve Doğa Bilimleri Fakültesi, Bitki Koruma Bölümü, BOLU

*Sorumlu yazar: alicelik@ibu.edu.tr

Geliş Tarihi: 07.09.2018

Düzeltme Geliş Tarihi: 28.09.2018

Kabul Tarihi: 28.09 .2018

Özet

Ülkemizde önemli bir üretim potansiyeline sahip olan fasulyede Bean common mosaic virus (BCMV), Bean common mosaic necrosis virus (BCMNV) viral hastalık etmenleri önemli verim kayıplarına yol açmaktadır. Son yıllarda yaygınlaşan moleküler markörler yardımıyla dayanıklıık genlerinin tespiti çalışmaları virüs inokulasyonu gerekmeksizin bitkilerde söz konusu genlerin belirlenebilmesini mümkün kılmaktadır. Bu çalışmada ülkemizde yer alan 43 tescilli fasulye çeşidinde BCMV ve BCMNV virüslerine karşı muhtemel dayanıklılık 3 farklı gen $\left(b c-1^{2}\right.$, I, $b c-3$ ) ile ilişkili 4 farklı markör (SBD-5, SW-13, ROC11/420-350, elFE4) yardımıyla incelenmiştir. Elde edilen verilere göre 43 fasulye çeşidinin BCMV ve BCMNV etmenlerine karşı dayanıkıııkta rol oynayan bazı genlere sahip olduğu belirlenmiştir. Elde edilen markör destekli tarama sonuçlarının virüs inokulasyonu ve patojenisite çalışmaları ile desteklenmesi öngörülmüştür. Söz konusu markörler yardımıyla yerel fasulye çeşitlerinin ve çeşit tescil adaylarının virüslere dayanıkııık genleri değerlendirilerek tescil özelliklerinin güçlendirilebileceği düşünülmektedir.

Anahtar kelimeler: Fasulye, BCMV, BCMNV, dayanıklılık, gen.

\section{Identification of Genes Related to Resistance for Bean common mosaic virus and Bean common mosaic necrosis virus in Commercial Common Bean Cultivars in Turkey}

\begin{abstract}
Bean common mosaic virus (BCMV) and Bean common mosaic necrosis virus (BCMNV) pathogens lead to significant yield losses in common bean, which have a significant production potential in our country. The identification of resistance genes with the help of molecular markers has become widespread in recent years due to possibility to determine the genes in plants without virus inoculation. In this study, probable resistance to $B C M V$ and $B C M N V$ viruses in 43 commercial bean cultivars in our country were examined using 4 different markers (SBD-5, SW-13, ROC11/420-350, elFE4) related to 3 genes $\left(\left(b c-1^{2}, l, b c-3\right)\right.$. According to the obtained data, 43 commercial bean cultivars were found to have some genes which play a role in resistance to BCMV and BCMNV pathogens. The obtained marker-assisted screening results are supposed to be supported by virus inoculation and pathogenicity studies. With the help of these molecular markers, it is considered that the registry characteristics of the common bean landraces and candidate beans for registration can be supported by checking the resistance genes of the viruses.
\end{abstract}

Key words: Bean common, BCMV, BCMNV, resistance, gene.

\section{Giriş}

Fasulye (Phaseolus vulgaris L.), Leguminosae familyasında yer alan bir baklagil bitkisidir. Taze ve kuru olarak tüketilebilen fasulyenin insan beslenmesinde önemli bir yeri vardır (Bozoğlu, 1995). Tüik (2017) verilerine göre ülkemizde 267 
$\mathrm{kg} /$ da olmak üzere 897.221 da alanda kuru fasulye üretimi yapılmış olup ayrıca 630.347 ton taze fasulye üretimi gerçekleştirilmiştir. Ülkemiz tarımının önemli faaliyetleri asarında yer alan fasulye yetiştiriciliğinde birçok fungal, bakteriyel ve viral etmen hastalığa neden olmakta ve ürün kayıplarına yol açmaktadır (Deligöz ve ark., 2015). Bean common mosaic virus (BCMV) ve Bean common necrosis mosaic virus (BCMNV) fasulyenin dünyada ve ülkemizde en yaygın ve ekonomik açıdan önemli olan virüsleri arasında yer almaktadır. Hem BCMV hem de BCMNV, tek iplikçikli, pozitif duyarlılıkta bir RNA genomuna sahiptir (Larsen ve ark., 2011). Potyviridae familyası, Potyvirus cinsinde yer alan BCMV ve BCMNV yaprak bitleri ile nonpersistent şekilde taşınmakta, ayrıca mekanik olarak bitki öz suyu ile tarımsal ekipmanlarla, tohumla ve polenle yayılabilmektedir.

Fasulye bitkisinde BCMNV ve BCMV izolatlarına karşı dayanıklılık, bir adet dominant I geni ve dört adet resesif gen $\left(b c-u, b c-1 / b c-1^{2}, b c-\right.$ $2 / b c-2^{2}$ ve $b c-3$ ) olmak üzere beş farklı dayanıklılık geniyle sağlanmaktadır. Ayrıca $b c-1$ ve $b c-2$ genlerin her biri ikişer allele sahiptir (Drijfhout 1978). BCMNV ve BCMV etmenleri, söz konusu beş dayanıklılık geniyle ilgili olarak 1 ila 8 arasında numaralandırılmış 8 farklı patogruba (PG) ayrılmaktadır (Feng ve ark. 2017). BCMNV sadece PG-3 ve PG-6 ile ilişkili bulunurken BCMV, sekiz grubun hepsiyle ilişkili olarak bulunabilmektedir (Feng ve ark., 2015).

Dominant I geninin $30{ }^{\circ} \mathrm{C}$ 'nin altındaki sıcaklıklarda BCMV'nin tüm ırklarına karşı dayanıklılık sergilediği ve simptomların maskelendiği rapor edilmesine rağmen $30{ }^{\circ} \mathrm{C}$ nin üstündeki sıcaklıklara bitkide genel nekroz hakimiyetinin görüldüğü bildirilmiştir (Collmer ve ark., 2000). I geni bulunduran çeşitlerin ticari fasulye yetiştiriciliğinde tercih edilmesinden bu yana BCMNV'e karşı çeşit hassasiyetlerinde artışlar gözlenmiştir. BCMV ve BCMNV' e karşı dayanıklı olduğu değerlendirilen çeşitlerde zaman zaman sistemik enfeksiyon görülse de ilave bazı genler ile bu durumun genel nekroza dönüşmediği görülmüştür (Feng ve ark., 2017).

1992 yılından önce BCMNV, BCMV'nin bir alt türü olarak düşünülmüş, bu sebepten ötürü biyolojik çalışmalar sıklıkla BCMV üzerinden yürütülmüştür (Vetten ve ark. 1992). Bu sebeple fasulyenin önemli bir viral hastalığı olan BCMNV hakkında hala kısıtlı bilgi mevcuttur. Öyle ki GenBank veri kayıtları incelendiğinde BCMNV ile ilgili oldukça az sayıda dizi bilgisinin yer aldığı görülmektedir. Bu bilgi eksikliğinin giderilmesinde virüse ait genomik sekans bilgilerinin yanı sıra, fasulye bitkisinin sahip olduğu dayanıklılık genlerinin de incelenmesi gerekmektedir. Bu sayede BCMNV'e ait değişik PG gruplarının açığa çıkarılması mümkün olacaktır (Feng ve ark., 2017) .

Markör yardımıyla dayanıklılık genlerinin tespiti çalışmaları virüs inokulasyonuna gerek duymadan bitkilerde söz konusu genlerin belirlenebilmesine imkân sağlayabilmesi nedeniyle günümüzde yoğun olarak kullanılan bir yöntemdir. $\mathrm{Bu}$ yöntem, moleküler testlerin akabinde virüs inokulasyonu ile kombine edilerek, özellikle virüslere karşı dayanıklı gen havuzu oluşturma ve seleksiyon programlarında kolaylıklar sağlamaktadır. Ülkemizde yapılan bir çalışmada Deligöz ve Sökmen (2013) ikisi tescilli olmak üzere beş fasulye çeşidi ve bir ıslah hattının BCMV ve BCMNV"ye karşı dayanıklılık düzeylerinin ve sahip oldukları dayanıklılık genlerinin durumlarını ilgili genlere spesifik primerler ile PCR yapmak suretiyle kontrol etmişlerdir. Gerçekleştirdiğimiz bu çalışmada Tohumluk Tescil ve Sertifikasyon Merkez Müdürlüğü tarafından tescillenmiş olan 43 adet fasulye çeşidi (Tablo 1) BCMV ve BCMNV virüslerine karşı sahip oldukları genlerin varlığı bakımından incelenmiş, dayanıklılığa işaret eden söz konusu genlerin moleküler karakterizasyonları gerçekleştirilmiştir.

\section{Materyal ve Yöntem}

Çalışmada kullanılan fasulye çeşitlerine ait tohumlar $23^{\circ} \mathrm{C}$ sıcaklıkta çimlendirilmiş, 3-5 yapraklı döneme ulaşan bitkilerden DNA izolasyonu GeneJET Plant Genomic DNA Purification Kit (Thermo Scientific) kullanılarak ilgili firmanın talimatları doğrultusunda gerçekleştirilmiştir. Her bir fasulye çeşidinden ve kontrol amacıyla temin edilen (USDAARS) ayırıcı set genotiplerinden (Tablo 3) elde edilen DNA'lar, virüslere dayanıklılığı ifade eden farklı genlerle ilişkili moleküler markörler yardımıyla taranmıştır. Bu amaçla Tablo 2'de belirtilen markörler kullanılmıştır. PCR amplifikasyonları 0.2 $\mu \mathrm{M}$ dNTPs, $0.3 \mu \mathrm{M}$ primer, $1.5 \mathrm{mM} \mathrm{MgCl}$, $\mathrm{PCR}$ buffer, 10-20 ng DNA, $1 \cup$ Taq DNA polimeraz içeren $25 \mu \mathrm{l}^{\prime}$ lik hacimlerde gerçekleştirilmiştir. Elde edilen PCR ürünlerini \%1.4'lük agaroz jelde 100 V'da elektroforetik olarak ayrılarak gözlemlenmiştir. Beklenilen PCR ürünlerinin büyüklükleri ise $100 \mathrm{bp}$ DNA ladder kullanılarak tespit edilmiştir.

\section{Bulgular ve Tartışma}

$B C M V$ ve $B C M N V$ virüslerine karşı fasulye çeşitlerinde dayanıklılık sağlayan gen lokuslarının moleküler markörlerle belirlenmesi için yapılan çalışmada 43 fasulye genotipinden DNA ekstraksiyonu yapılmış ve bu örnekler 4 farklı markör ile incelenmiştir. PCR sonuçlarına göre virüslere dayanıklılıktan sorumlu genlerin testlenen çeşitler bünyesindeki dağılımı Tablo 4 'de gösterilmiştir. 
Tablo 1. Çalışmada kullanılan tescilli fasulye genotipleri.

\begin{tabular}{clccccccc}
\hline No & Çeşit adı & Tür adı & No Çeşit adı & Tür adı & No Çeşit adı & Tür adı \\
\hline 1 & Zülbiye & KF $^{*}$ & 16 & Batallı & KF & 31 & Cihan & KF \\
2 & Remi & TF $^{*}$ & 17 & Göksun & KF & 32 & Bulduk & KF \\
3 & Özdemir & KF & 18 & Mecidiye & KF & 33 & 40 Günlük & TF \\
4 & Kantar-05 & KF & 19 & 4F-89 Fransız & TF & 34 & Bourgondia & TF \\
5 & Sazova 1949 & TF & 20 & Bona & TF & 35 & Karabacak & TF \\
6 & Gina & TF & 21 & Romano 26 & TF & 36 & Akın & KF \\
7 & Karacaşehir 90 & KF & 22 & Klas & TF & 37 & Akman 98 & KF \\
8 & Alman Ayşe-4 & TF & 23 & Göynük 98 & KF & 38 & Terzibaba & KF \\
9 & Zirve & KF & 24 & Güngör & KF & 39 & Önceler 98 & KF \\
10 & Işıklı & TF & 25 & Elkoca-05 & KF & 40 & Berrak & KF \\
11 & Askız & TF & 26 & Sembol & TF & 41 & Yakutiye 98 & KF \\
12 & Mina & TF & 27 & Aras 98 & KF & 42 & Akdağ & KF \\
13 & Sarıkız & TF & 28 & Nina & TF & 43 & Arslan & KF \\
14 & Helda & TF & 29 & Sururbey & KF & & \\
15 & Albeni & TF & 30 & Sülün & TF & & & \\
\hline
\end{tabular}

${ }^{*}$ KF: Kuru Fasulye, TF: Taze Fasulye.

Tablo 2. Markörler ve PCR koşulları.

\begin{tabular}{|c|c|c|c|c|c|}
\hline Primer & Dizi & Döngüler & Gen & Bant & Kaynak \\
\hline SW-13 & $\begin{array}{l}\text { 5'-CACAGCGACATTAATTTTCCTTTC-3' } \\
\text { 5'-CACAGCGACAGGAGGAGCTTATTA -3' }\end{array}$ & $\begin{array}{l}95^{\circ} \mathrm{C} \quad 4 \mathrm{~min} ; \\
94^{\circ} \mathrm{C} 10 \mathrm{~s}, 60^{\circ} \mathrm{C} \\
40 \mathrm{~s}, 72^{\circ} \mathrm{C} 2 \\
\text { min } 35 \text { döngü } \\
\text { ve } 72^{\circ} \mathrm{C} 5 \mathrm{~min}\end{array}$ & I geni & 690 & $\begin{array}{l}\text { Haley et al., } \\
1994 \text { Melotto } \\
\text { et al., } 1996 \\
\text { Fourie et } \\
\text { al.,2004 }\end{array}$ \\
\hline SBD-5 & $\begin{array}{l}\text { 5'-GTGCGGAGAGGCCATCCATTGGTG-3' } \\
\text { 5'-GTGCGGAGAGTTTCAGTGTTGACA-3' }\end{array}$ & $\begin{array}{l}95^{\circ} \mathrm{C} \quad 4 \mathrm{~min} ; \\
94^{\circ} \mathrm{C} 10 \mathrm{~s}, 65^{\circ} \mathrm{C} \\
40 \mathrm{~s}, 72^{\circ} \mathrm{C} 2 \\
\text { min } 35 \text { döngü } \\
\text { ve } 72^{\circ} \mathrm{C} 5 \mathrm{~min}\end{array}$ & $b c-1^{2}$ & 1250 & $\begin{array}{l}\text { Miklas et al., } \\
2000\end{array}$ \\
\hline Roc11 & $\begin{array}{l}\text { 5'-CCAATTCTCTTTCACTTGTAACC-3' } \\
\text { 5'-GCATGTTCCAGCAAACC - } 3^{\prime}\end{array}$ & $\begin{array}{l}95^{\circ} \mathrm{C} \quad 4 \mathrm{~min} ; \\
94^{\circ} \mathrm{C} 10 \mathrm{~s}, 65^{\circ} \mathrm{C} \\
10 \mathrm{~s}, 72^{\circ} \mathrm{C} 30 \mathrm{~s} \\
35 \text { döngü ve } \\
72^{\circ} \mathrm{C} 5 \text { min }\end{array}$ & $b c-3$ & 420 & $\begin{array}{l}\text { Johnson et al., } \\
1997\end{array}$ \\
\hline elFE4 & $\begin{array}{l}\text { 5'-ACCGATGAGCAAAACCCTA-3' } \\
\text { 5'-CAACCAACTGGTATCGGATT-3' }\end{array}$ & $\begin{array}{l}95^{\circ} \mathrm{C} 3 \mathrm{~min} ; \\
94^{\circ} \mathrm{C} 20 \mathrm{~s}, 58^{\circ} \mathrm{C} \\
20 \mathrm{~s}, 72^{\circ} \mathrm{C} 20 \mathrm{~s} \\
40 \text { döngü ve } \\
72^{\circ} \mathrm{C} 5 \text { min }\end{array}$ & $b c-3$ & $\begin{array}{c}541 \\
(381 / 160)\end{array}$ & $\begin{array}{l}\text { Naderpour et } \\
\text { al., } 2010\end{array}$ \\
\hline
\end{tabular}

Tablo 3. Çalışmada kullanılan ayırıcı settler (USDA-ARS).

\begin{tabular}{cc} 
Genotip & Gen Havuzu \\
\hline Michelite & $M A^{*}$ \\
MDRK (Michigan Dark Red Kidney) & $A^{*}$ \\
Perry Marrow & $A$ \\
Cornell 49242 & $M A$ \\
Widusa & $M A$ \\
TO & $M A$ \\
TU & $M A$ \\
Ouro Negro & $M A$ \\
\hline
\end{tabular}

\footnotetext{
${ }^{*} \mathrm{MA}=$ Middle American gen havuzu; $\mathrm{A}=\mathrm{Andean}$ gene havuzu.
} 
Tablo 4. Çeşitlerin sahip olduğu dayanıklılık genlerinin dağılımı.

\begin{tabular}{|c|c|c|c|c|c|}
\hline No & Çeşit & $b c-1^{2}$ (SBD-5) & I geni (SW-13) & $b c-3$ (ROC11) & bc-3 (eIFE4) \\
\hline 1 & Zülbiye & + & + & + & - \\
\hline 2 & Remi & + & + & + & - \\
\hline 3 & Özdemir & + & - & + & - \\
\hline 4 & Kantar-05 & + & - & + & - \\
\hline 5 & Sazova 1949 & + & + & + & - \\
\hline 6 & Gina & + & + & + & - \\
\hline 7 & Karacaşehir 90 & + & - & + & - \\
\hline 8 & Alman Ayşe-4 & + & + & + & - \\
\hline 9 & Zirve & + & + & + & - \\
\hline 10 & Işıklı & + & + & + & - \\
\hline 11 & Askız & + & + & + & - \\
\hline 12 & Mina & + & + & + & - \\
\hline 13 & Sarıkız & + & + & + & - \\
\hline 14 & Helda & + & - & + & - \\
\hline 15 & Albeni & + & + & + & - \\
\hline 16 & Batallı & - & + & + & - \\
\hline 17 & Göksun & + & - & + & - \\
\hline 18 & Mecidiye & + & - & + & - \\
\hline 19 & 4F-89 Fransız & + & - & - & + \\
\hline 20 & Bona & + & + & + & - \\
\hline 21 & Romano 26 & + & + & + & - \\
\hline 22 & Klas & + & + & + & - \\
\hline 23 & Göynük 98 & + & + & + & - \\
\hline 24 & Güngör & + & - & + & - \\
\hline 25 & Elkoca-05 & + & - & + & - \\
\hline 26 & Sembol & + & + & + & - \\
\hline 27 & Aras 98 & + & + & + & - \\
\hline 28 & Nina & + & + & + & - \\
\hline 29 & Sururbey & + & + & + & - \\
\hline 30 & Sülün & + & + & + & - \\
\hline 31 & Cihan & + & + & + & - \\
\hline 32 & Bulduk & + & + & + & - \\
\hline 33 & 40 Günlük & + & - & + & - \\
\hline 34 & Bourgondia & + & + & + & - \\
\hline 35 & Karabacak & + & - & + & - \\
\hline 36 & Akın & + & + & + & - \\
\hline 37 & Akman 98 & - & + & + & - \\
\hline 38 & Terzibaba & + & + & + & - \\
\hline 39 & Önceler 98 & + & + & + & - \\
\hline 40 & Berrak & + & + & + & - \\
\hline 41 & Yakutiye 98 & + & + & + & - \\
\hline 42 & Akdağ & + & + & + & - \\
\hline 43 & Arslan & - & + & - & - \\
\hline
\end{tabular}

Moleküler taramalar neticesinde SBD-5 markörü yardımıyla 1250 bp büyüklüğünde bantlar elde edilmiştir (Şekil 1). SBD-5 markörü ile yapılan taramalarda Batallı ve Arslan çeşitleri haricindeki 41 adet çeşidin, söz konusu $b c-1^{2}$ genine sahip olduğu belirlenmiştir. Elde edilen sonuçlar beklenen bant büyüklüğü bakımından ve çalışmada taranan çeşitlerdeki $b c-1^{2}$ geninin oransal dağılımı açısından Pasev ve ark. (2014) ile örtüşmektedir. Ülkemizde Deligöz ve Sökmen (2013) SBD-5 markörünü kullanarak 5 fasulye çeşidi ve 1 ıslah hattı ile yürüttükleri çalışmada bütün örneklerin $b c-1^{2}$ genine sahip olduklarını belirlemişlerdir. Bilgilerimize göre fasulyede $b c-1^{2}$ geninin varlığının tespitinde SBD-5 markörünün (Miklas ve ark., 2000) dışında kullanılan başka bir markör bulunmamaktadır. Yüksek pozitif sonuçların varlığı sebebiyle SBD-5 markörü ile $b c-1^{2}$ geninin varlığının tespitinde yardımcı unsurlarla desteklenmesinin gerektiği bildirilmiştir (Strausbaugh ve ark., 2003). Bu çalışmada, SBD-5 markörü ile ilgili $b c-1^{2}$ geni neredeyse çeşitlerin tamamında pozitif sinyal 
vermiştir. I geninin varlığının tespitinde kullanılan SW-13 markörü ile yapılan taramalarda 690 bp büyüklüğünde amplifikasyonlar gerçekleşmiş ve 32 çeşidin I genine sahip olduğu belirlenmiştir. Bu sonuçlara göre Haley ve ark. (1994) Melotto ve ark. (1996); Pasev ve ark. (2014) ile aynı büyüklükte bant görüntüleri elde edilmiştir. Ülkemizde Deligöz ve Sökmen (2013) 5 fasulye çeşidi ve 1 ıslah hattında I geninin varlığının tespiti amacıyla SW-13 ve SBD-15 markörü ile multiplex-PCR ile taramışlardır. Elde edilen sonuçlara göre SW-13 markörü ile 690 bp büyüklüğünde bantlar elde edilmiş ve Özeren Şeker, 4F-3260 ve Zülbiye çeşitlerinin pozitif bant görüntüleri verdiğini belirlemişlerdir. Araştırma sonuçlarına göre Zülbiye çeşidi I geninin varlığı bakımından pozitif bant vermiştir. Zülbiye çeşidinin I genine sahip olması bakımından benzer sonuçlar göstermekle beraber, söz konusu çeşidin virüslere dayanıkılık bakımından tercih edilebilirliğini kuvvetlendirmiştir. Diğer bir SCAR markör olan ROC11/420-350 primeri ile çeşitler arasında $b c-3$

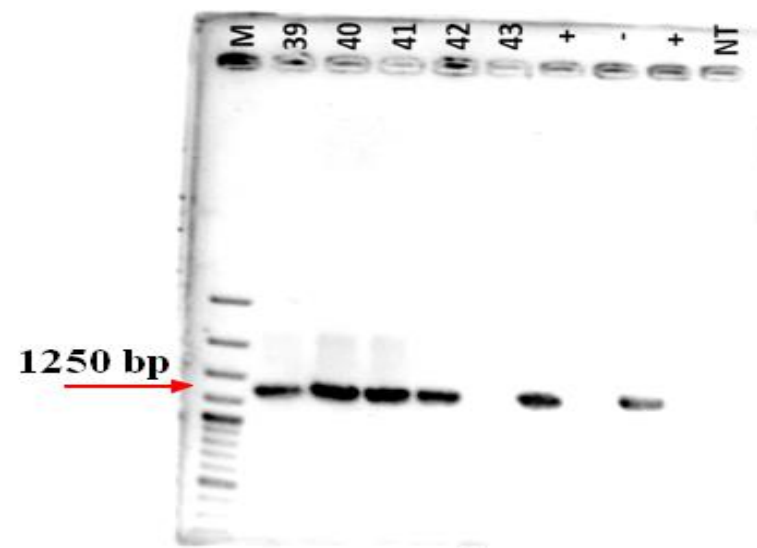

A

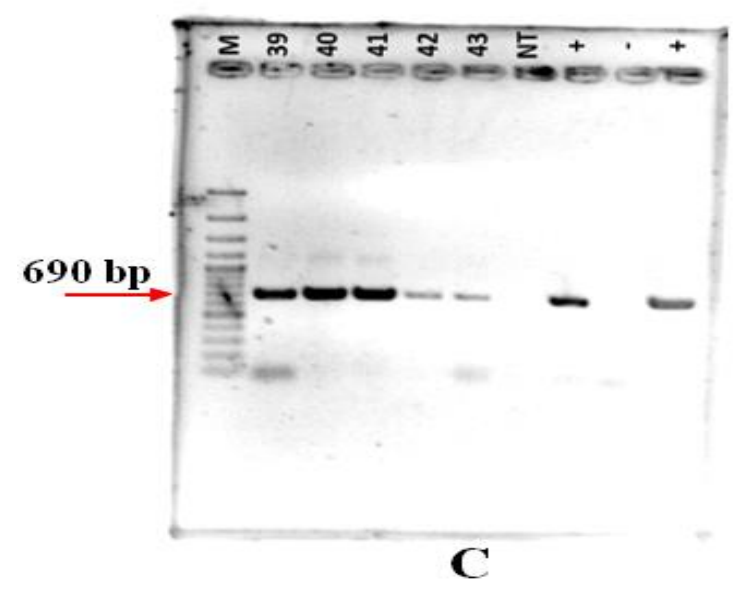

Şekil 1. Araştırmada oluşan bant profilleri.

A) SBD-5 markörü ile elde edilen bir bant görüntüsü. M: Marker, 39: Önceler-98 40: Berrak, 41:Yakutiye 98, 42: Akdağ, 43: Arslan, Perry Marrow (+), Cornell $49242(-)$, Michigan Dark Red Kidney (+), NT: Non-template. geninin varlığı aranmıştır. Beklenen 420 bp büyüklüğünden farklı olarak 350 bp büyüklüğünde bantlar elde edilmiştir. Araştırma bulguları ile beklenen sonuçlar arasındaki bu farklılığa Pasev ve ark. (2014)'da da rastlanılmıştır. Bu farklılığın SW-13 primerinin yüksek delesyon oluşturma potansiyelinden dolayı meydana geldiği varsayılmaktadır. Beklenenden farklı büyüklükte bant görüntüleri elde edilmiş de olsa $b c-3$ geninin varlığının teyit edildiği varsayılmakta olup ilgili 41 çeşidin $b c-3$ genine sahip olduğu değerlendirilmiştir. Bir CAPS markör olan ve $b c-3$ geninin varlığının saptanmasında kullanılan elFE4 ile yapılan taramalar neticesinde sadece 1 çeşidin (4F-89Fransız) $b c-3$ genine sahip olduğu belirlenmiştir. Elde edilen sonuçlara göre çalışmamız Naderpour ve ark. (2010) ile benzerlik göstermiştir. Pozitif bant veren örnekler Rsal enzimiyle kesilmiş (Naderpour ve ark., 2010) ve sadece bir çeşitte (4F-89 Fransız) 381+160 bp büyüklüğünde bant profilleri elde edilmiştir (Şekil 1).
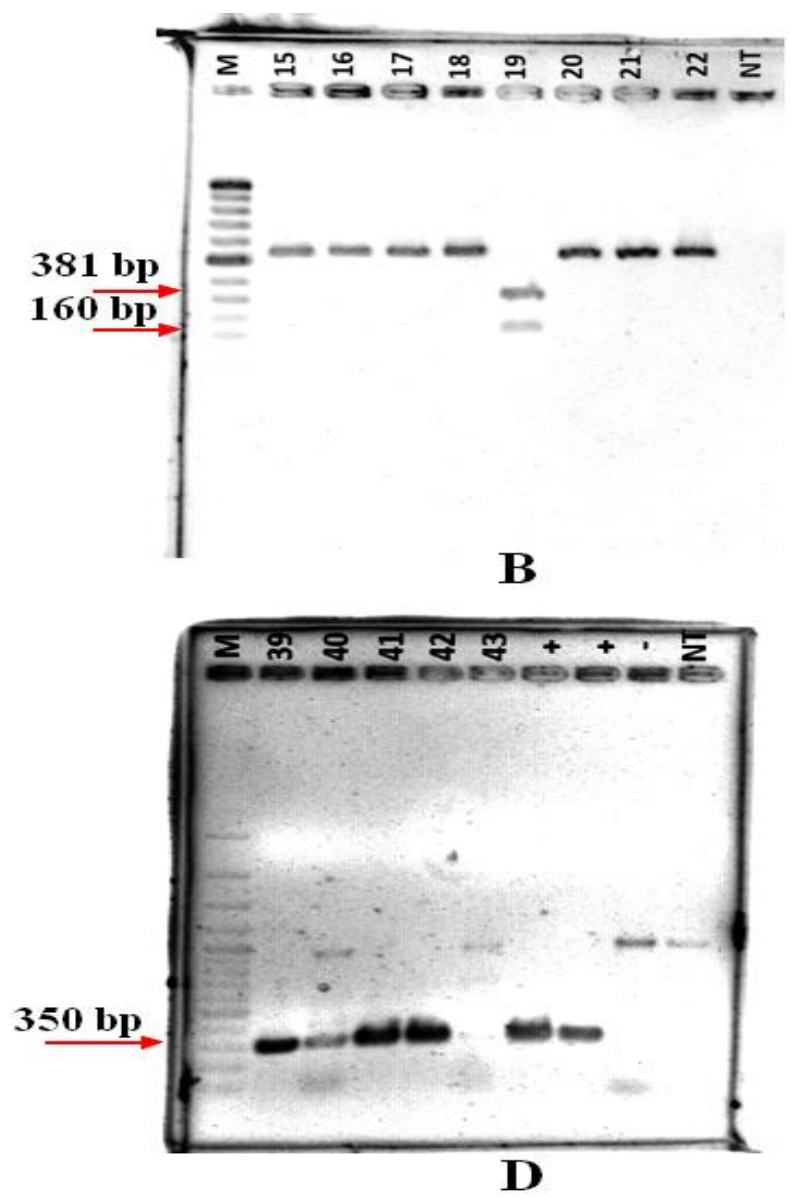

B) elF4E markörü ile elde edilen bir bant görüntüsü. M: Marker, 15: Albeni, 16: Batallı, 17: Göksun, 18: Mecidiye, 19: 4F-89 Fransız, 20: Bona, 21: Romano-26, 22: Klas, NT: Non-template (Rsal enzimiyle kesilmiştir). 
C) SW-13 markörü ile elde edilen bir bant görüntüsü. M: Marker, 39: Önceler-98 40: Berrak, 41:Yakutiye 98, 42: Akdağ, 43: Arslan, NT: Nontemplate, TO $(+)$, Michigan Dark Red Kidney (-), Widusa (+).

D) ROC11/420-350 markörü ile elde edilen bir bant görüntüsü. M: Marker, 39: Önceler-98 40: Berrak, 41:Yakutiye 98, 42: Akdağ, 43: Arslan, Perry Marrow (+), TO (+), Cornell $49242(-)$, NT: Nontemplate.

\section{Sonuç ve Öneriler}

Bu çalışmada kullanılan 43 fasulye çeşidinin $B C M V$ ve BCMNV'ye karşı dayanıklılıkta rol oynayan bazı genlere sahip olduğu belirlenmiştir. Elde edilen moleküler veriler ışığında dayanıklıı geni bulunduran çeşitlerin virüs inokulasyonuyla desteklenerek reaksiyonlarının ölçülmesi çalışmanın çıktılarını destekleyecektir. İnokulasyon sonucu elde edilen sonuçların moleküler veriler ile birlikte değerlendirilmesi fenotipik olarak markörlerin başarısını teyit etmiş olacaktır. Ülkemizin yerel üretim profili göz önüne alındığında fasulye açısından tescil adayı ümitvar fasulye hatlarının söz konusu virüslere dayanıklılık bakımından incelenmesi önerilmektedir. Elde edilen verilerin, ıslah çalışmalarını destekleyici özellikte olması öngörülmektedir.

\section{Kaynaklar}

Bozoğlu, H. 1995. Kuru Fasulyede Bazı Tarımsal Özelliklerin Genotip x Çevre İnteraksiyonu ve Kalıtım Derecelerinin Belirlenmesi Üzerine Bir Araştırma. Yayınlanmamış Doktora Tezi. 19 May. Ünv. Fen Bil. Enst., $99 \mathrm{~s}$.

Collmer, C.W., Marston, M.F., Taylor, J.C., Jahn, M. 2000. The I gene of bean: a dosagedependent allele conferring extreme resistance, hypersensitive resistance, or spreading vascular necrosis in response to the potyvirus Bean common mosaic virus. Molecular plant-microbe interactions, 13(11): 1266-1270.

Deligöz, i., Sökmen, M.A. 2013. Bazı fasulye genotiplerinin Bean common mosaic virus (BCMV) ve Bean common mosaic necrosis virus (BCMNV)'a dayanıklılık durumlarının kalitatif, kantitatif ve moleküler yöntemlerle belirlenmesi. Bitki Koruma Bülteni, 53(2): 101-113.

Deligöz, İ., Sarı, S., Karaağaç, O. 2015. Karadeniz Tarımsal Araştırma Enstitüsü tarafından geliştirilen taze fasulye ıslah hatları ve bazı ticari çeşitlerin Bean common mosaic virus (BCMV)'a dayanıklılık durumlarının araştırılması. Derim, 32(1): 1-10.
Drijfhout, E. 1978. Genetic Interaction Between Phaseolus vulgaris and Bean Common Mosaic Virus with Implications for Strain Identification and Breeding for Resistance. Centre for Agricultural Publication and Documents, Wageningen, the Netherlands.

Feng, X., Guzmán, P., Myers, J.R., Karasev, A.V. 2017. Resistance to Bean common mosaic necrosis virus Conferred by the bc-1 Gene Affects Systemic Spread of the Virus in Common Bean. Phytopathology, 107(7): 893-900.

Feng, X., Myers, J.R., Karasev, A.V. 2015. Bean common mosaic virus isolate exhibits a novel pathogenicity profile in common bean, overcoming the bc-3 resistance allele coding for the mutated EIF4E translation initiation factor. Phytopathology 105: 1487-1495.

Fourie, D., Miklas, P., Ariyaranthe, H. 2004. Genes conditioning halo blight resistance to races 1,7 , and 9 occur in a tight cluster. Annual Report-Bean Improvement Cooperative, 47: 103-104.

Haley, S.D., Afanador, L., Kelly, J.D. 1994. Identification and application of a random amplified polymorphic DNA marker for the I gene (potyvirus resistance) in common bean. Phytopathology, 84(2): 157-160.

Johnson, W.C., Guzmán, P., Mandala, D., Mkandawire, A.B.C., Temple, S., Gilbertson, R.L., Gepts, P. 1997. Molecular tagging of the $\mathrm{BC}-3$ gene for introgression into Andean common bean. Crop Science, 37(1): 248-254.

Larsen, R.C., Druffel, K.L., Wyatt, S.D. 2011. The complete nucleotide sequences of bean common mosaic necrosis virus strains NL5, NL-8 and TN-1. Arch. Virol., 156: 729732.

Melotto, M., Afanador, L., Kelly, J.D. 1996. Development of a SCAR marker linked to the I gene in common bean. Genome, 39(6): 1216-1219.

Miklas, P.N., Stone, V., Daly, M.J., Stavely, J.R., Steadman, J.R., Bassett, M.J., Delorme, R., Beaver, J.S. 2000. Bacterial, fungal, and viral disease resistance loci mapped in a recombinant inbred common bean population ('Dorado'/XAN 176). J. Am. Soc. Hort. Sci., 125: 476-481.

Naderpour, M., Lund, O. S., Larsen, R., Johansen, E. 2010. Potyviral resistance derived from cultivars of Phaseolus vulgaris carrying BC3 is associated with the homozygotic presence of a mutated elF4E 
allele. Molecular plant pathology, 11(2): 255-263.

Pasev, G., Kostova, D., Sofkova, S. 2014. Identification of genes for resistance to Bean common mosaic virus and Bean common mosaic necrosis virus in snap bean (Phaseolus vulgaris L.) breeding lines using conventional and molecular methods. Journal of Phytopathology, 162(1): 19-25.

Strausbaugh, C.A., Miklas, P.N., Singh, S.P., Myers, J.R., Forster, R.L. 2003. Genetic characterization of differential reactions among host group 3 common bean cultivars to NL-3 K strain of Bean common mosaic necrosis virus. Phytopathology, 93(6): 683-690.

TÜik, 2017. Türkiye İstatistik Kurumu. http://www.tuik.gov.tr/ (Erişim tarihi: 25.07.2018).

Vetten, H.J., Lesemann, D.E., Maiss, E. 1992. Serotype A and B strains of bean common mosaic virus are two distinct potyviruses. In Potyvirus Taxonomy, pp. 415-431, Springer, Vienna. 